\title{
AN UNUSUAL SPRING IN THE JACKSON RIVER, BATH COUNTY, VIRGINIA
}

William $K$. Jones

KarstWatersInstitute,wkj30@hotmail.com

\section{Philip C. Lucas}

Virginia Speleological Survey,Lucas@virginiacaves.org
All of the sinking streams traced to Boiling Spring are on the eastern side of the Jackson River from Hidden Valley to the Richardson Gorge $3.2 \mathrm{~km}$ (2 mi) south of Bacova. The surface topography ranges from anticlinal ridges to rolling pastureland in the western portion of the Valley and Ridge physiographic province. Detailed geologic mapping is unavailable for the study area. A 1:100,000 scale geologic map (Rader and Wilkes, 2001) lumps all of the rocks as undivided Devonian and Silurian and little structural detail is given. A much more detailed description of the stratigraphic units is presented in Swezey et al. (2015). The rocks seen in road banks are primarily sandstones and shales with limestones exposed in water gaps cutting the anticlinal ridges of infeeder streams and along the Jackson River. All of the steam sinks traced to Boiling Spring are at the contact of the Licking Creek Limestone with the overlying Oriskany Sandstone so most of the recharge to the spring is allogenic water flowing off of the surrounding clastic rocks. Boiling Spring appears in a meander bend of the Jackson river and is probably near the axis of an anticline that brings the older Keyser Limestone to the surface.

\section{Bath Boiling Spring}

The Bath County Boiling Spring is on private property on the Jackson River downstream from Bacova in western

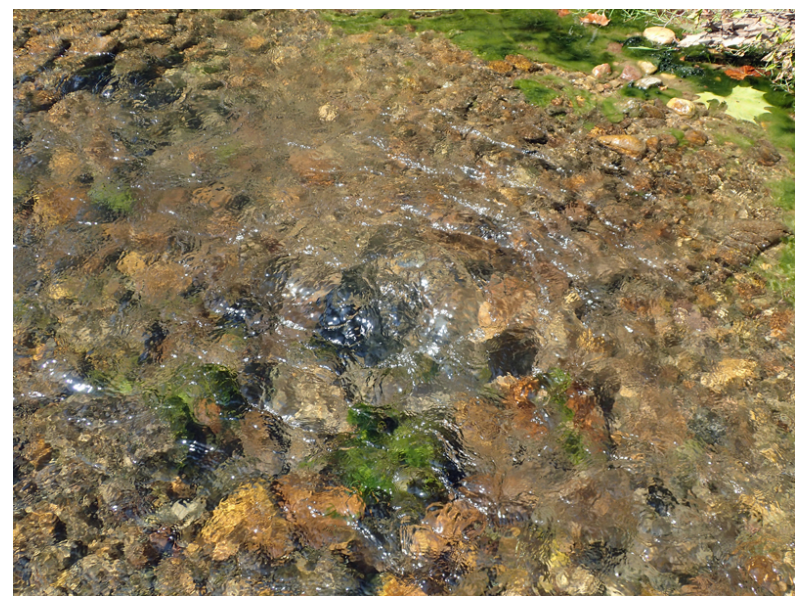

Figure 1. Photo showing Boiling Spring at low flow (photo by W. K. Jones). 
Bath County. The spring is $1.4 \mathrm{~km}(0.9 \mathrm{mi})$ downstream from the U.S. Geological Survey gaging station (USGS 02011400) near Bacova (Figure 2). Water discharging at Boiling Spring is mostly the return of surface water from several tributary streams to the Jackson River that sink in their beds before reaching the river during dry periods. All of the tributaries traced to the spring have been infeeders on the east side of the river (Figure 2). The stream traces are summarized in Table 1.

The Jackson River was monitored for dye using passive carbon detectors at three locations above Boiling Spring, the spring itself, and one location downstream of the spring. Two other springs along the river upstream from Boiling Spring were also monitored using passive carbon detectors. Grab samples were collected at Boiling Spring at two to four day intervals. The presence and relative concentrations of the tracer dyes were measured using a Shimadzu RF5000U recording spectrofluorophotometer. The tracers were only found at Boiling Spring and the downstream Jackson River station.

The nearest sinking stream that has been traced to Boiling Spring is water from Warm Springs Run. This stream rises as a thermal spring (about $36^{\circ} \mathrm{C}$, or $97^{\circ} \mathrm{F}$ )

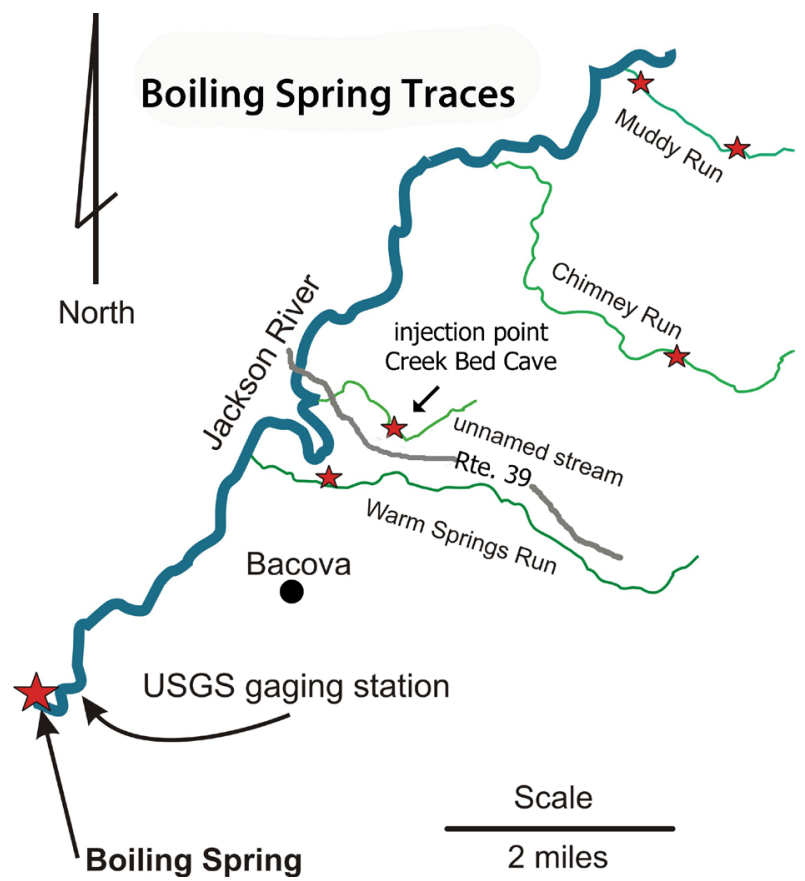

Figure 2. Sketch map showing the tracer tests to Boiling Springs. Small stars show location of sink points used for dye injection and large star is Boiling Springs (map by P.C. Lucas; 1 mile $=1.6 \mathrm{~km}$ ).

\begin{tabular}{|l|c|c|c|c|}
\hline Swallet & Date & Dye (lbs) & $\begin{array}{c}\text { Travel } \\
\text { (days) }\end{array}$ & $\begin{array}{c}\text { Distance } \\
\mathrm{km}(\mathrm{mi})\end{array}$ \\
\hline $\begin{array}{l}\text { Warm Spr } \\
\text { Run }\end{array}$ & $9 / 14 / 2005$ & Eosin (2) & $<3$ & $4.8(3.0)$ \\
\hline $\begin{array}{l}\text { Creek Bed } \\
\text { Cave }\end{array}$ & $8 / 16 / 2005$ & $\begin{array}{c}\text { Fluorescein } \\
(2)\end{array}$ & $<5$ & $6.4(4.0)$ \\
\hline $\begin{array}{l}\text { Chimney } \\
\text { Run }\end{array}$ & $10 / 03 / 2005$ & $\begin{array}{c}\text { Rhodamine } \\
(3)\end{array}$ & $<10$ & $9.7(6.0)$ \\
\hline $\begin{array}{l}\text { Muddy Run } \\
\text { (E) }\end{array}$ & $8 / 16 / 2005$ & $\begin{array}{c}\text { Rhodamine } \\
(3)\end{array}$ & $4<\mathrm{d}<11$ & $12.5(7.75)$ \\
\hline $\begin{array}{l}\text { Muddy Run } \\
\text { (W) }\end{array}$ & $9 / 28 / 2005$ & $\begin{array}{c}\text { Fluorescein } \\
(1)\end{array}$ & $<4$ & $12.2(7.6)$ \\
\hline
\end{tabular}

Table 1. Tracer tests to Boiling Spring.

and flows to the southwest joining the Jackson River above Bacova. This water is highly mineralized and the water at Boiling Spring appears to be even more highly mineralized and contains sulfur species probably originating from Warm Springs.

Creek Bed Cave is in a small valley (Figure 3) and normally captures most of the flow from this unnamed tributary. This sink is just north of Rte. 39 and is the one stream that does not reach the river on the surface. A couple of miles to the north of Creek Bed Cave, Chimney Run sinks under low flow conditions and resurges at Boiling Spring.

Muddy Run sinks in its bed in two different places before reaching the Jackson River junction upstream from Hidden Valley. The first insurgence, about a mile above the mouth of the run, is located at the east flank of the Cobbler Mountain Anticline, capturing a part of the Muddy Run stream into a small cave at creek level (Figure 4). The straight-line distance to Boiling Spring is $12.5 \mathrm{~km}(7.75 \mathrm{mi})$ and this is the longest reported tracer test in Virginia. The second insurgence, on the west

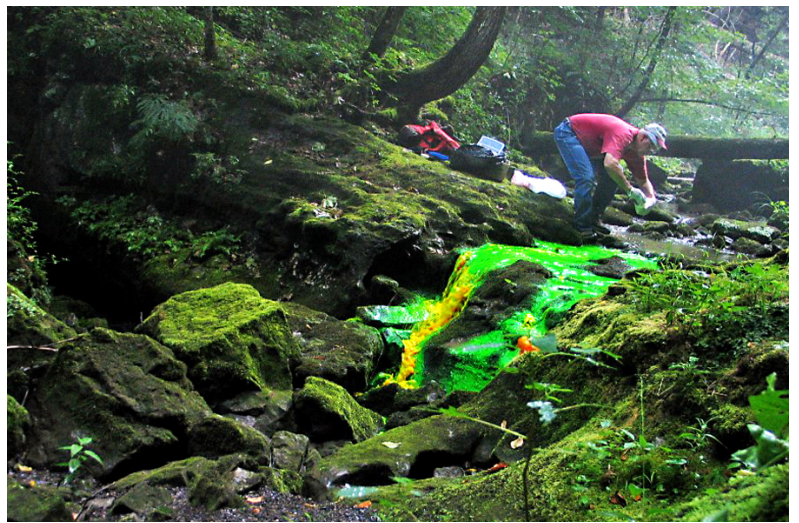

Figure 3. Dye injection at Creek Bed Cave (photo by W. K. Jones). 


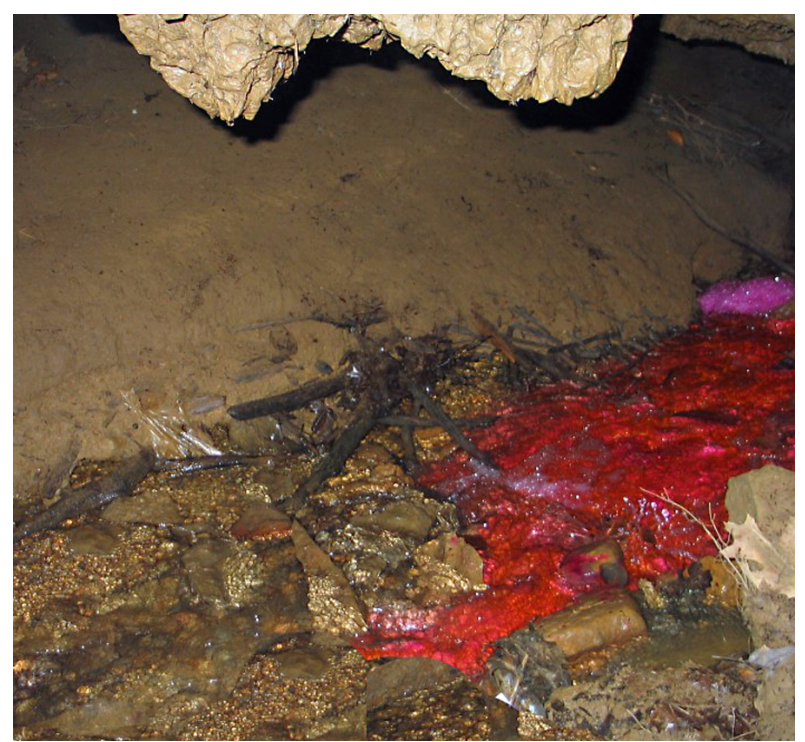

Figure 4. Dye injection at the upper Muddy Run Cave insurgence (photo by W. K. Jones).

flank of the anticline occurs at a limestone outcrop in the stream bed. Clastic rocks separate these two sink points.

\section{Conclusions}

A discharge measurement at the spring during low flow conditions of October 2005 showed the spring discharge at $0.36 \mathrm{~m}^{3} / \mathrm{s}(12.8 \mathrm{cfs})$. The discharge at the gaging station just upstream of the spring was $0.77 \mathrm{~m}^{3} / \mathrm{s}$ $(27.0 \mathrm{cfs})$, so the total flow for this reach of the river should be about $1.13 \mathrm{~m}^{3} / \mathrm{s}$ ( $\left.40 \mathrm{cfs}\right)$. The under-reporting of the flow for this station is probably not significant at high water levels. The reported drainage basin area of $409 \mathrm{~km}^{2}\left(158 \mathrm{mi}^{2}\right)$ would be changed very slightly if the gaging station could be moved downstream of the spring. The calculated annual runoff of $371 \mathrm{~mm}$ (14.6 in) per year seems low compared to $480 \mathrm{~mm}$ (18.9 in) per year for the nearby Bullpasture River at Williamsville and other gaging stations with a similar water budget.

This is a rather immature karst area but has potential for significant cave development. These dye traces establish that an area about $12.9 \mathrm{~km}(8 \mathrm{mi})$ long and $4.8 \mathrm{~km}(3 \mathrm{mi})$ wide is being drained by underground flow routes. Despite a surface that lacks well-developed karst and has only a few small caves, there are probably many miles of caves below the Oriskany Sandstone caprock.

\section{References}

Rader EK, Wilkes GP. 2001. Geologic map of the Virginia portion of the Staunton $30 \times 60$ minute quadrangle. Virginia Division of Mineral Resources. Publication 163. 1 sheet, 1;100,000 scale.

Swezey CS, Haynes JT, Lambert RA, White WB, Lucas PC, Garrity CP. 2015. The geology of Burnsville Cove, Bath and Highland Counties, Virginia. In: White WB, ed. The caves of Burnsville Cove, Virginia. Switzerland: Springer International Publishing, p. 299-334. 
